\title{
Latent sensitisation to respiratory syncytial virus during acute bronchiolitis and lung function after recovery
}

\author{
S J Caswell, A H Thomson, S P Ashmore, C S Beardsmore, H Simpson
}

\begin{abstract}
To determine whether latent sensitivity to respiratory syncytial virus antigen(s) occurs after infection, 27 infants with acute bronchiolitis were studied and compared with 15 hospital controls. Blood was collected for whole blood challenge, and histamine release was measured by a high performance liquid chromatography technique with fluorometric detection. There was a significantly greater histamine release to respiratory syncytial virus antigen(s) in those with bronchiolitis than in controls, expressed either in amount (median $154 \mathrm{nmol} / \mathrm{l}$ compared with $104 \mathrm{nmol} / \mathrm{l}$ ) or percentage release (median $20 \%$ compared with $3 \%$ ). There was a significant difference between index and control groups in terms of individual histamine responses. These findings strongly suggest that infants develop latent sensitivity to respiratory syncytial virus antigen(s) during the course of acute bronchiolitis.

Serial lung function tests were performed in 15 infants. All infants had abnormalities of lung function at some stage, but the small numbers of subjects precluded comparison between 'sensitised' and 'non-sensitised' infants. Further study is indicated to define the relation of latent sensitisation and subsequent bronchial hyper-responsiveness after respiratory syncytial virus infection in infants.
\end{abstract}

Infections with respiratory syncytial virus occur in epidemics every winter in the United Kingdom, and are the main cause of acute bronchiolitis in infancy. ${ }^{1}$ The virus is also associated with the sudden infant death syndrome (SIDS), which has a peak age range (2 to 6 months) similar to that of acute bronchiolitis. ${ }^{2}$ Allergic sensitisation of the airways as a result of infection with respiratory syncytial virus has been postulated as an explanation for increased respiratory morbidity after apparent recovery from acute bronchiolitis, ${ }^{34}$ and as a mechanism of death in some cases of SIDS. ${ }^{5} 6$ The hypothesis of modified anaphylaxis as a cause of SIDS presupposes that mast cells and basophils are sensitised in some way by $\operatorname{IgE}$ and then release chemical mediators on subsequent exposure to specific allergens. Latent anaphylactic sensitivity of infants to allergens has been shown experimentally by assay of histamine release from blood on exposure to specific allergens-for example cows' milk proteins. ${ }^{7}$

The main aim of the present study was to find out whether latent sensitivity to respiratory syncytial virus antigen(s) occurs during the course of attacks of acute bronchiolitis in infancy, and whether there may be a relationship between latent sensitivity and lung function (including the responsiveness of airways to histamine) after apparent recovery from the acute illness.

\section{Patients and methods}

LATENT SENSITIVITY

\section{Patients}

Twenty seven infants with bronchiolitis (mean age 17 weeks, range 3-42) were studied during the $1987 / 8$ winter outbreak of respiratory syncytial virus infection. Fifteen infants (mean age 13 weeks, range 1-35), in hospital for nonrespiratory illnesses, were studied as a control group. Six had been born after the end of the 1986/7 winter outbreak of respiratory syncytial virus infection and were studied before the onset of the 1987/8 outbreak.

The clinical details and course of the illness were carefully recorded for each index case. Nasopharyngeal aspirates were obtained so that viruses could be identified by indirect immunofluorescence and tissue culture. During venepuncture for routine clinical investigations an additional $2 \mathrm{ml}$ venous blood was obtained for 'challenge' studies.

\section{Challenge reagents}

Goat antihuman IgE (E chain specific) was obtained from Sigma Chemicals (minimum titre 1:8).

Respiratory syncytial virus antigen consisted of respiratory syncytial virus strain A2 grown in Hep 2 cells with a standard 199 tissue culture medium containing added fetal calf serum proteins and antibiotics. The culture was centrifuged and the supernatant (containing respiratory syncytial virus antigen) collected for use in basophil challenges.

The control tissue culture (containing no respiratory syncytial virus) antigen consisted of uninfected Hep 2 cells grown in the same medium and then centrifuged, the supernatant being retained for use in the challenge test.

Pasteurised whole cows' milk was centrifuged at $8200 \mathrm{~g}$ for five minutes and the middle layer retained for use in the challenge studies.

\section{Sample challenges}

Venous blood was put in bottles containing lithium heparin and stored at $4^{\circ} \mathrm{C}$. Preparation
Correspondence to:

Accepted 4 April 1990 
and challenge of the blood were carried out within three hours of collection to minimise histamine breakdown and extracellular histamine release from the basophils. After gentle mixing, the blood was divided into five $250 \mu \mathrm{l}$ samples each of which was diluted with $250 \mu$ l phosphate buffered saline. Samples were then challenged with $50 \mu$ l of reagent and basophil histamine release was measured.

The individual sample challenges were:

- Goat antihuman IgE

- Respiratory syncytial virus antigen in tissue culture

- Control tissue culture (containing no respiratory syncytial virus)

- Pasteurised whole cows' milk

- Phosphate buffered saline (control).

Two infants who had been fed exclusively on breast milk had a sixth sample challenged with their mothers' breast milk.

The samples were agitated at $150 \mathrm{rpm}$ and $37^{\circ} \mathrm{C}$ for 45 minutes to permit basophil histamine release to occur in response to the challenge, and then diluted .with $250 \mu \mathrm{l}$ of phosphate buffered saline and centrifuged at $3700 \mathrm{~g}$ for 10 minutes. The cell free supernatant was removed from each sample and the residual cellular component was made up to the same volume with phosphate buffered saline. Both the supernatant and the cellular components were deproteinised by the addition of an equal volume of $0.8 \mathrm{M}$ perchloric acid. This was followed immediately by vortex mixing for one minute and incubation at room temperature for 30 minutes. The extracts were precipitated by centrifugation at $3700 \mathrm{~g}$ for 10 minutes. The supernatant containing histamine was then collected and diluted with an equal volume of distilled water, and the residues containing protein were discarded. A standard preparation of $250 \mu \mathrm{l}$ of histamine hydrochloride $1 \mathrm{mmol} / \mathrm{l}$ was also taken through the assay.

\section{Histamine assay}

The samples were cleaned by passing them through a Sep-Pak C18 cartridge, and the histamine was measured by high performance liquid chromatography with fluorometric detection that permits measurement in nmol concentrations. ${ }^{8}$ The histamine release was also expressed as a percentage of the total available histamine present in the basophils. ${ }^{7}$

\section{Statistical analysis}

The computerised Statistical Package for the Social Sciences was used. The data were not normally distributed, so non-parametric tests were used for analysis. The significance of differences was assessed by the Mann-Whitney $\mathrm{U}$ test, and the $\chi^{2}$ test was used to compare differences between proportions.

FOLLOW UP ASSESSMENT OF LUNG FUNCTION Fifteen of the original 27 infants admitted to hospital with acute bronchiolitis entered the follow up study. Their median age on admission to hospital was 11 weeks (range 4-21). None had pre-existing respiratory disorders or had been treated with mechanical ventilation during the course of the illness. Laboratory assessment of latent sensitivity was carried out at a median of six days (range 2-15) from the onset of the illness. The infants returned for clinical assessment and lung function tests at a mean (SD) of nine weeks ( 3 days) and 31 weeks ( 3 days), respectively, after discharge.

A standard protocol was followed for assessment of lung function. Each infant was sedated with chloral hydrate $100 \mathrm{mg} / \mathrm{kg}$, and studied in an infant whole body plethysmograph (modified Jaeger) to measure thoracic gas volume and airways resistance. The infant (still asleep) was then placed in a polythene squeeze jacket with a face mask and pneumotachograph, and six or eight satisfactory partial expiratory flow volume (PEFV) curves were recorded to obtain a value for maximum flow at functional residual capacity ('ंmaxFRC). ${ }^{9}$ A bronchial histamine challenge was then performed, provided that the infant had no clinical signs of lower airways obstruction; that the oxygen saturation measured by the Ohmeda Biox $\mathbf{3 7 0 0}$ oximeter was greater than 90\%; and that the PEFV curves were clearly distinguishable from tidal breathing curves at the end of expiration. Repeated inhalations of histamine phosphate were delivered by a Wright's nebuliser starting at a concentration of $0.25 \mathrm{~g} / \mathrm{l}$, and PEFV curves were repeated between each inhalation. ${ }^{10}$ The challenge ended when a response to histamine occurred, judged by the shape of the PEFV curve. The procedure was stopped if the oxygen saturation fell below $90 \%$. The dose of histamine necessary to produce a $30 \%$ fall in VmaxFRC was then calculated (provocative dose- $\mathbf{P D}_{\mathbf{3 0}}$ ). Details of the infant's clinical course after apparent recovery from bronchiolitis were noted.

\section{Ethical approval}

This study was approved by the Leicestershire Health Authority ethics committee. Informed consent was obtained from the parents of all infants after a thorough explanation of the nature of the study, and the tests and procedures to be undertaken.

\section{Results}

\section{LATENT SENSITISATION}

Comparability of the groups

There were significantly more boys in the control group than in the index group; no other differences were found (table 1).

\section{Identification of viruses}

Respiratory syncytial virus was identified from nasopharyngeal aspirates in 16 of the 27 infants in the index group. There were no significant differences in the clinical presentation or course of these infants when compared with those in whom respiratory syncytial virus was not identified (table 2). 


\section{Histamine release}

When index and control groups are considered separately, neither age nor interval between onset of illness and blood sample had a significant effect on either total histamine release or on histamine release in response to the various challenges undertaken.

Within the bronchiolitis group no differences were observed between those infants who did and those who did not have respiratory syncytial virus isolated for any of the variables measured.

Table 1 Comparability of the groups

\begin{tabular}{|c|c|c|}
\hline & $\begin{array}{l}\text { Infants with } \\
\text { bronchiolitis } \\
(n=27)\end{array}$ & $\begin{array}{l}\text { Control } \\
\text { infants } \\
(n=15)\end{array}$ \\
\hline $\begin{array}{l}\text { Mean (range) age (weeks) } \\
\text { Mean (SD) gestation (weeks) } \\
\text { Mean (SD) birthweight (g) } \\
\text { Male:female ratio } \\
\text { Feeding: }\end{array}$ & $\begin{array}{l}17(3-42) \\
38 \cdot 7(2 \cdot 2) \\
3170(610) \\
10: 17^{*}\end{array}$ & $\begin{array}{l}13(1-35) \\
39 \cdot 6(1 \cdot 1) \\
3360(580) \\
13: 2^{*}\end{array}$ \\
\hline Breast milk & \\
\hline Cows' milk & 18 & 8 \\
\hline & 5 \\
\hline $\begin{array}{l}\text { Vomiting or possetting: } \\
\text { None }\end{array}$ & & 5 \\
\hline $\begin{array}{l}\text { Mild } \\
\text { Severe }\end{array}$ & 5 & 3 \\
\hline Severe & 4 & 7 \\
\hline \multicolumn{3}{|l|}{ Smoking: } \\
\hline Mother & 12 & 4 \\
\hline Father & 12 & 9 \\
\hline Family history of atopic disorder & 17 & 5 \\
\hline
\end{tabular}

Table 2 Clinical details of the 27 infants with bronchiolitis

\begin{tabular}{|c|c|c|}
\hline & $\begin{array}{l}\text { Infants in whom respiratory } \\
\text { syncytial virus identified } \\
(n=16)\end{array}$ & $\begin{array}{l}\text { Infants in whom } \\
\text { virus not identified } \\
(n=11)\end{array}$ \\
\hline \multirow{4}{*}{$\begin{array}{l}\text { Mean (SD) maximum respiratory } \\
\text { rate/min } \\
\text { Mean (SD) maximum heart rate/min } \\
\text { Mean (SD) maximum temperature }\left({ }^{\circ} \mathrm{C}\right) \\
\text { No of infants receiving: } \\
\text { Added oxygen } \\
\text { Ventilation } \\
\text { Intravenous fluids } \\
\text { No of infants with apnoeic episodes } \\
\text { ( }>20 \mathrm{~s} \text { ) } \\
\text { Median (range) days in hospital } \\
\text { Median (range) days between onset } \\
\text { of illness and venesection }\end{array}$} & $\begin{array}{l}71 \cdot 4(14 \cdot 4) \\
164 \cdot 1(18 \cdot 3) \\
37 \cdot 8(0 \cdot 6)\end{array}$ & $\begin{array}{l}59 \cdot 5(15 \cdot 6) \\
154 \cdot 1(13 \cdot 2) \\
37 \cdot 5(0 \cdot 52)\end{array}$ \\
\hline & $\begin{array}{l}\left.9 \text { (range } \mathrm{F}_{1} \mathrm{O}_{2} \quad 30-85 \%\right) \\
5\end{array}$ & $\begin{array}{l}\left.4 \text { (range } \mathrm{F}_{\mathrm{I}} \mathrm{O}_{2} \quad 30-45 \%\right) \\
1 \\
1\end{array}$ \\
\hline & $\begin{array}{l}1 \\
6(3-15)\end{array}$ & $\begin{array}{l}2 \\
5(1-14)\end{array}$ \\
\hline & $6(3-14)$ & $5(2-15)$ \\
\hline
\end{tabular}

$\mathrm{F}_{1} \mathrm{O}_{2}=$ fractional inspired oxygen.
Thus the findings for the bronchiolitis group have been combined.

-The results of the challenge tests for both groups of infants are given in table 3 . Within the bronchiolitis group significantly more histamine was released on challenge with anti$\operatorname{IgE}(\mathrm{p}<0.0005)$ and respiratory syncytial virus antigen $(p<0.003)$ than on the control challenge with phosphate buffered saline. No differences were observed among challenges with tissue culture medium containing no respiratory syncytial virus, cows' milk, and phosphate buffered saline. The response to challenge with anti-IgE antibody was significantly greater than either that to tissue culture containing no respiratory syncytial virus $(p<0.003)$ or that to cows' milk $(p<0.02)$. Histamine release to challenge with respiratory syncytial virus antigen(s) was greater than with respiratory syncytial virus culture medium, but this difference was not significant $(p<0.09)$. There were no significant differences within the control group. When the index and control groups were compared there was a significantly greater release of histamine in reponse to challenge with respiratory syncytial virus antigen among infants with bronchiolitis than among controls $(p<0.05)$.

The percentage histamine release in response to challenge in the index and control groups of infants is given in table 4. Within the bronchiolitis group the response to challenge with respiratory syncytial virus antigen was significantly greater than the responses to tissue culture containing no respiratory syncytial virus $(\mathrm{p}<0.003)$ or to phosphate buffered saline $(p<0.003)$; among controls there was a significant difference between challenges with antiIgE antibody and culture medium containing no respiratory syncytial virus $(p<0.05)$. The only significant difference between the two groups was in the response to challenge with respiratory syncytial virus antigen(s); this was significantly increased among infants with bronchiolitis $(\mathrm{p}<0.05)$. There were no differences between the groups in response to challenge with cows' milk.

Table 3 Histamine release in response to challenge

\begin{tabular}{|c|c|c|c|c|c|c|}
\hline & \multicolumn{3}{|c|}{ Infants with bronchiolitis $(n=27)$} & \multicolumn{3}{|c|}{ Control infants $(n=15)$} \\
\hline & $\begin{array}{l}\text { Mean } \\
\text { (nmol/l) }\end{array}$ & $\begin{array}{l}\text { Median } \\
(\text { nmolll })\end{array}$ & $\begin{array}{l}I Q R \\
(\text { nmolll })\end{array}$ & $\begin{array}{l}\text { Mean } \\
(\text { nmol/l) }\end{array}$ & $\begin{array}{l}\text { Median } \\
\text { (nmolll) }\end{array}$ & $\begin{array}{l}I Q R \\
\text { (nmolll) }\end{array}$ \\
\hline $\begin{array}{l}\text { Control (phosphate buffered saline) } \\
\text { IgE antibody } \\
\text { Respiratory syncytial virus antigen } \\
\text { Respiratory syncytial virus control } \\
\text { Cows'milk }\end{array}$ & $\begin{array}{l}106 \\
187 \\
172^{* *} \\
129^{*} \\
131\end{array}$ & $\begin{array}{l}104 \\
183 \\
154 \\
130 \\
141\end{array}$ & $\begin{array}{r}61-146 \\
126-247 \\
129-228 \\
78-189 \\
72-174\end{array}$ & $\begin{array}{l}93 \\
155 \\
113^{* *} \\
90 \\
97\end{array}$ & $\begin{array}{r}97 \\
126 \\
104 \\
84 \\
104\end{array}$ & $\begin{array}{l}23-130 \\
71-239 \\
14-192 \\
33-147 \\
24-153\end{array}$ \\
\hline Total & 478 & 395 & $235-678$ & 454 & 365 & $264-568$ \\
\hline
\end{tabular}

${ }^{*} p<0 \cdot 09$ : difference between respiratory syncytial virus antigen and respiratory syncytial virus culture medium in bronchiolitis group. ${ }^{* *} \mathrm{p}<0.05$ : difference between respiratory syncytial virus antigen responses between bronchiolitis and control group of infants. IQR, interquartile range.

Table 4 Percentage histamine release in response to challenge

\begin{tabular}{|c|c|c|c|c|c|c|}
\hline & \multicolumn{3}{|c|}{ Infants with bronchiolitis $(n=27)$} & \multicolumn{3}{|c|}{ Control infants $(n=15)$} \\
\hline & $\begin{array}{l}\text { Mean } \\
\text { (percent) }\end{array}$ & $\begin{array}{l}\text { Median } \\
\text { (percent) }\end{array}$ & $\begin{array}{l}I Q R \\
\text { (percent) }\end{array}$ & $\begin{array}{l}\text { Mean } \\
\text { (percent) }\end{array}$ & $\begin{array}{l}\text { Median } \\
\text { (percent) }\end{array}$ & $\begin{array}{l}I Q R \\
\text { (percent) }\end{array}$ \\
\hline $\begin{array}{l}\text { IgE antibody } \\
\text { Respiratory syncytial virus antigen } \\
\text { Respiratory syncytial virus control } \\
\text { Cows' milk }\end{array}$ & $\begin{array}{l}23 \\
25^{* *} \\
10^{* *} \\
18\end{array}$ & $\begin{array}{r}24 \\
20 \\
2 \\
5\end{array}$ & $\begin{array}{r}11-34 \\
6-33 \\
0-18 \\
0-17\end{array}$ & $\begin{array}{c}20 \\
12^{*} \\
4 \\
6\end{array}$ & $\begin{array}{r}14 \\
3 \\
0 \\
0\end{array}$ & $\begin{array}{l}0-27 \\
0-25 \\
0-5 \\
0-13\end{array}$ \\
\hline
\end{tabular}

${ }^{*} \mathrm{p}<0.05$ : difference between respiratory syncytial virus antigen responses between bronchiolitis and control groups of infants ${ }_{*}^{*} p<0 \cdot 003$ : difference between respiratory syncytial virus antigen and respiratory syncytial virus culture medium in bronchiolitis group. IQR, interquartile range. 
Individual responses

After scrutiny of the distribution of responses of individual infants in the study groups, the release of $15 \%$ or more histamine was taken as a positive response to challenge. By this criterion, 20 of the 27 infants with bronchiolitis and five of the 15 controls had positive responses to respiratory syncytial virus antigen; the numbers for challenge with culture medium containing no respiratory syncytial virus were seven and one. A $10 \%$ cut off point gave similar results. A positive response to challenge with respiratory syncytial virus does not, therefore, necessarily indicate latent sensitisation to respiratory syncytial virus antigen(s). In seven infants in the bronchiolitis group, and one in the control group, the results were 'uninformative' in that positive results were obtained from challenges both with respiratory syncytial virus antigen(s) and with the culture medium containing no respiratory syncytial virus. Table 5 shows the individual responses taking this into account; there was a significant difference between the bronchiolitis and . control group $\left(\chi^{2}=6 \cdot 93\right.$; $\mathrm{p}<0.01$ ). Further examination of 'uninformative' data indicated that the difference in percentage release of histamine between challenge with respiratory syncytial virus antigen and with tissue culture containing no respiratory syncytial virus exceeded $15 \%$ in a further three infants with bronchiolitis and one control infant. Adjusting the results given in table 5 to include these infants as positive responders to respiratory syncytial virus antigen(s) does not alter the significance of the original analysis.

There was a wide range of response to cows' milk challenge. Six of 23 infants investigated in the index group showed a response of $15 \%$ or

Table 5: Individual responses to challenge with respiratory syncytial virus antigen(s)

\begin{tabular}{lll}
\hline & $\begin{array}{l}\text { Infants with } \\
\text { bronchiolitis } \\
(n=27)\end{array}$ & $\begin{array}{l}\text { Control } \\
\text { infants } \\
(n=15)\end{array}$ \\
\hline $\begin{array}{l}\text { Response to antigen }>15 \%, \\
\text { response to culture }<15 \%\end{array}$ & $13(16)$ & $4(5)$ \\
$\begin{array}{l}\text { Response to both antigen and } \\
\text { culture }>15 \% \text { ('uninformative') }\end{array}$ & $7(4)$ & 1 \\
$\begin{array}{l}\text { Response to both antigen } \\
\text { and culture <15\% }\end{array}$ & 7 & 10 \\
\hline
\end{tabular}

Figures in parentheses include those infants in whom antigen and virus free culture histamine release were $>15 \%$. more, compared with three of 13 control infants. All six who responded to cows' milk in the index group also responded to respiratory syncytial virus antigens, and four responded to culture medium containing no respiratory syncytial virus. There was, however, concordance of responses between cows' milk and culture medium containing no respiratory syncytial virus in 19 of the 23 infants studied. In the control group, three who responded to cows' milk also responded to respiratory syncytial virus antigen(s), and one responded to culture medium containing no respiratory syncytial virus. There was concordance of response between milk and culture medium containing no respiratory syncytial virus in 11 of 13 infants studied.

\section{Clinical aspects}

Seventeen cases and five control infants had family histories of asthma or atopic disorders in first degree relatives. This did not influence their response to any of the challenges undertaken. Four infants in the bronchiolitis group and two control infants were breast fed (without additional milk) at the time of testing. Three of these six infants gave positive responses to challenge with cows' milk. Of two infants fed exclusively on breast milk one responded equally to challenges with breast milk and cows' milk, and the other to neither challenge.

\section{LUNG FUNCTION}

The results of tests of latent sensitivity and lung function for the 15 children studied are shown in table 6. Eleven had developed latent sensitivity during their acute illnesses. Two (cases 14 and 15) were readmitted to hospital before the first set of lung function measurements with severe respiratory infections (attributed to adenovirus, type unknown); they continued to have symptoms throughout the period of study. Of the remaining 13 infants, two showed hyperinflation (thoracic gas volume $>120 \%$ predicted) and five had raised airways resistance $(>140 \%$ predicted) at the first test. All infants had substantially reduced VंmaxFRC values, and only four fulfilled the criteria for inhalational histamine challenge (mean (SD) $\mathrm{PD}_{30}=0.4(0.2)$ g/l).

Table 6 Details of results of latent sensitisation and lung function in 15 infants

\begin{tabular}{|c|c|c|c|c|c|c|c|c|c|c|c|}
\hline \multirow[t]{2}{*}{$\begin{array}{l}\text { Case } \\
\text { No }\end{array}$} & \multirow{2}{*}{$\begin{array}{l}\text { Duration of } \\
\text { admission } \\
\text { (days) }\end{array}$} & \multirow[t]{2}{*}{$\begin{array}{l}\text { Infant } \\
\text { sensitised }\end{array}$} & \multicolumn{2}{|c|}{$\begin{array}{l}\text { Thoracic gas volume } \\
\text { (\% of predicted) }\end{array}$} & \multicolumn{2}{|c|}{$\begin{array}{l}\text { Airways resistance } \\
\text { (\% of predicted) }\end{array}$} & \multicolumn{2}{|c|}{$\begin{array}{l}\dot{V} \max F R C \\
(\% \text { of predicted })\end{array}$} & \multicolumn{2}{|c|}{$\begin{array}{l}\text { Provocative dose } e_{30} \\
(\mathrm{~g} / \mathrm{l})\end{array}$} & \multirow{2}{*}{$\begin{array}{l}\text { Symptoms present } \\
\text { between discharge } \\
\text { and time of last } \\
\text { lung function test }\end{array}$} \\
\hline & & & Test 1 & Test 2 & Test 1 & Test 2 & Test 1 & Test 2 & Test 1 & Test 2 & \\
\hline $\begin{array}{r}1 \\
2 \\
3 \\
4 \\
5 \\
6 \\
7 \\
8 \\
9 \\
10 \\
11 \\
12 \\
13 \\
14 \\
15\end{array}$ & $\begin{array}{r}3 \\
11 \\
5 \\
2 \\
2 \\
5 \\
7 \\
1 \\
3 \\
5 \\
6 \\
8 \\
6 \\
3 \\
9\end{array}$ & $\begin{array}{l}\text { Yes } \\
\text { No } \\
\text { Not known } \\
\text { No } \\
\text { Yes } \\
\text { Not known } \\
\text { Yes } \\
\text { Yes } \\
\text { Yes } \\
\text { Yes } \\
\text { Yes } \\
\text { Yes } \\
\text { Yes } \\
\text { Yes } \\
\text { Yes }\end{array}$ & $\begin{array}{r}124 \\
107 \\
71 \\
100 \\
90 \\
71 \\
97 \\
72 \\
126 \\
74 \\
92 \\
105 \\
77 \\
\text { Not re } \\
\text { Not re }\end{array}$ & $\begin{array}{r}89 \\
78 \\
74 \\
106 \\
77 \\
72 \\
106 \\
79 \\
126 \\
75 \\
89 \\
85 \\
85 \\
\text { lable } \\
\text { lable }\end{array}$ & $\begin{array}{c}88 \\
187 \\
197 \\
71 \\
90 \\
61 \\
85 \\
100 \\
147 \\
100 \\
144 \\
196 \\
134 \\
\text { Not record } \\
\text { Not record }\end{array}$ & $\begin{array}{r}87 \\
80 \\
100 \\
66 \\
93 \\
60 \\
100 \\
75 \\
236 \\
90 \\
142 \\
168 \\
123\end{array}$ & $\begin{array}{l}18 \\
\text { Tidal } \\
\text { Tidal } \\
27 \\
\text { Not done } \\
18 \\
32 \\
23 \\
\text { Tidal } \\
18 \\
12 \\
27 \\
60 \\
\text { Tidal } \\
\text { Tidal }\end{array}$ & $\begin{array}{l}30 \\
13 \\
8 \\
27 \\
16 \\
24 \\
39 \\
59 \\
\text { Tidal } \\
39 \\
13 \\
45 \\
37 \\
\text { Tidal } \\
\text { Tidal }\end{array}$ & $\begin{array}{l}0 \cdot 25 \\
\text { Not done } \\
\text { Not done } \\
\text { Not done } \\
\text { Not done } \\
\text { Not done } \\
0 \cdot 25 \\
0 \cdot 43 \\
\text { Not done } \\
\text { Not done } \\
\text { Not done } \\
\text { Not done } \\
0 \cdot 67 \\
\text { Not done } \\
\text { Not done }\end{array}$ & $\begin{array}{l}0 \cdot 25 \\
\text { Not done } \\
\text { Not done } \\
0 \cdot 3 \\
1 \\
0 \cdot 25 \\
1 \cdot 28 \\
1 \cdot 4 \\
\text { Not done } \\
0 \cdot 33 \\
\text { Not done } \\
0 \cdot 25 \\
0 \cdot 48 \\
\text { Not done } \\
\text { Not done }\end{array}$ & $\begin{array}{l}\text { No } \\
\text { Yes } \\
\text { Yes } \\
\text { Yes } \\
\text { Yes } \\
\text { No } \\
\text { No } \\
\text { No } \\
\text { Yes } \\
\text { Yes } \\
\text { Yes } \\
\text { Yes } \\
\text { Yes } \\
\text { Yes } \\
\text { Yes }\end{array}$ \\
\hline
\end{tabular}


At the second test, eight months after the original illness, eight infants showed functional improvement. One remained hyperinflated and three had raised airways resistance. The median $\dot{V}$ maxFRC had increased from 18 to $27 \%$ predicted. Nine infants fulfilled the criteria for histamine challenge (mean (SD) $\mathrm{PD}_{30}=0.62$ $(0 \cdot 47) \mathrm{g} / \mathrm{l})$. Severity of lung dysfunction in terms of overall mechanical properties was not associated with latent sensitisation during the acute illness, clinical severity of the acute bronchiolitis, duration of hospital stay, or the frequency and severity of symptoms that developed after discharge from hospital.

Paired data on responsiveness to inhaled histamine challenge was obtained for only four infants-all of whom were 'sensitised' to respiratory syncytial virus allergen(s). Paucity of data on 'non-sensitised' or uninformative cases does not permit comparison of 'sensitised' and 'non-sensitised' infants.

\section{Discussion}

LATENT SENSITISATION

The basophil histamine release system is an established laboratory model of the anaphylactic reaction. ${ }^{11}$ Assays can be carried out either in whole blood or in a preparation of washed white cells. Histamine release from whole blood was chosen for this study, as this system is more physiological and retains full viability and reactivity of the basophils. Basophil histamine release detects sensitisation of basophil by IgE antibodies specific to the allergen-in this case respiratory syncytial virus-and may be more sensitive than estimation of allergen specific circulating IgE, particularly if total IgE concentrations are low.

IgE mediated histamine release from basophils or whole blood may be influenced by many factors including age, allergic disease, and viral infection. The index and control groups were comparable with respect to age, allergic disease background, and total serum IgE and $\operatorname{IgG}_{4}$ concentrations. Interference from non-immune mechanisms of histamine release was minimised by using isotonic solutions when preparing the blood, and avoiding mechanical trauma to the basophils. None of the subjects had been given drugs that are known to release histamine. As we were interested in sensitisation to viral antigen(s), the time interval between infection and sampling was clearly important. There was, however, no correlation between the interval between the onset of illness and the time of taking the blood samples (median six days), and the total basophil histamine concentration or the release of histamine in response to the various challenges.

Histamine release is generally expressed as a percentage of the total histamine concentration. This is not an entirely satisfactory way to express the results of challenges in infants with low total histamine concentrations as a difference in histamine release, expressed in $\mathrm{nmol} / \mathrm{l}$, that is less than that caused by the variability of the method could produce a misleadingly large percentage histamine release. For this reason we have presented both actual histamine concen- trations and the percentage of histamine released.

Ethical constraints meant that venous blood samples were often taken before virological identification was complete. Respiratory syncytial virus was identified in 16 of the 27 infants with clinical bronchiolitis (59\%), which compares favourably with a reported sensitivity of immunofluorescence under ideal circumstances of $70 \%{ }^{12}$ The subgroup of infants in whom the virus was identified tended to have more severe acute illnesses, although individual indices of severity were not significant (table 2). Severity of illness is related to viral shedding in the respiratory tract and may account for the ease with which viruses could be identified. ${ }^{13}$ Infants in hospital with non-respiratory disorders were selected as the control group, the preponderance of boys being partly explained by the fact that several had congenital hypertrophic pyloric stenosis.

There is a wide range in whole blood histamine concentration in infancy and that reported in this study of $107-1251 \mathrm{nmol} / \mathrm{l}$ (equivalent to $22-230 \mathrm{ng} / \mathrm{ml}$ ) is higher than the range reported previously by McLaughlan and Coombs of 12-128 ng/ml. ${ }^{7}$ The histamine release to antiIgE was variable, and nine subjects (33\%) showed $<15 \%$ response to this challenge. Limitations in the size of the blood samples meant that challenges were made at only one concentration of anti-IgE, which may not have produced optimal release of histamine in each case. Our results are comparable with those of McLaughlan and Coombs, however, who reported that only $17 \%$ of the group showed no response to $\mathrm{IgE}_{\text {antibody. }}{ }^{7}$

Our results suggest that latent sensitivity to respiratory syncytial virus antigen(s) occurs during the course of infection with respiratory syncytial virus (tables 3 and 5). Both the within group and between group comparisons suggest that challenge with respiratory syncytial virus antigen has a significant effect on release of histamine from whole blood. Among individual infants 13 with bronchiolitis and four controls were considered respiratory syncytial virus 'responders' from their percentage release of histamine $(>15 \%)$. The figure indicating a significant percentage release of histamine, however, varies among published reports, McLaughlan chose $9 \%$ on the basis of an adult control population ${ }^{7}$; others have used $30 \%$ or $>50 \%$ of that produced by the optimal IgE concentration. ${ }^{14} 11$ We cannot explain the variations in responsiveness among infants in the bronchiolitis group, and have no information about whether interferon production or respiratory syncytial virus subtype influenced the results. ${ }^{15}$

The uncritical assumption that our results indicate allergic sensitisation to respiratory syncytial virus antigen(s) is not warranted. We did not include a 'control' virus challenge in our study design so that a non-specific viral effect cannot be excluded, although any such effect would have affected index and control groups of infants similarly. Perhaps of greater relevance is the finding of positive responses to challenge with culture medium containing no respiratory 
syncytial virus within both groups. This may be explained by the fact that the culture medium contained fetal calf serum proteins; it is for that reason that a cows' milk challenge was included in the study protocol. Parallel patterns of response to culture medium containing no respiratory syncytial virus, and to cows' milk, within both the index and control groups, suggests that 'sensitisation' to cows' milk proteins is an important confounding factor that could affect the interpretation of the results of challenge with respiratory syncytial virus antigen. The analysis given in table 5 tries to overcome this problem. The significant difference shown between the index and control groups may, however, have been caused as much by the distribution of 'uninformative' data as by any real difference in responsiveness to respiratory syncytial virus antigen(s).

'Sensitivity' to respiratory syncytial virus antigens was observed in five control infants with no previous history of respiratory illness. This finding may be spurious, as sensitisation to cows' milk protein would explain it in three infants. Previous sub-clinical respiratory syncytial virus infection cannot be excluded, however, in the remaining two in whom there was no response to challenge with cows' milk. It is of interest that five of the six infants born between seasonal epidemics of respiratory syncytial virus infection showed no response to either respiratory syncytial virus antigen or to cows' milk challenges; the remaining infant showed 'sensitisation' to both.

In their original paper on latent anaphylactic sensitisation to cows' milk protein, McLaughlan and Coombs extrapolated from data on normal adults and chose a $9 \%$ level of histamine release to indicate a degree of latent sensitivity. They reported that a quarter of their infants responded at this level, with roughly $10 \%$ releasing more histamine $(15-63 \%)$. The data on cows' milk from our infants (bronchiolitis and controls, $\mathbf{n}=37$ ) correspond with 12 infants showing $>9 \%$ histamine release, nine infants showing $>15 \%$ release, and five infants showing $>20 \%$ release. The lack of concordance between the response to the respiratory syncytial virus antigen and milk among the infants studied lends support to the notion that independent immunological reactions are occurring.

We did not measure antirespiratory syncytial virus IgE either during the acute illness or at follow up in any of the infants studied. Published reports of the detection of antirespiratory syncytial virus IgE some weeks after respiratory syncytial virus bronchiolitis, however, lend support to the interpretation of the present results-that allergic sensitisation to respiratory syncytial virus antigens occurs during the course of acute bronchiolitis. ${ }^{16} 17$

A great deal is now known about the immune response to respiratory syncytial virus infection but its role in the pathogenesis and protection against infection has yet to be fully clarified. Current knowledge in this area has been recently reviewed. ${ }^{18}$ The finding of antirespiratory syncytial virus specific IgE in nasopharyngeal secretions after respiratory syncytial virus infection is of most interest in the context of the present study. A systemic cell mediated response has also been described. ${ }^{19} 20$ There is, however, a growing suspicion that defective regulation of immune responses to respiratory syncytial virus infection is an important determinant in the outcome of the infection. ${ }^{21}$

Confirmation of latent sensitivity to respiratory syncytial virus infection indicates that there is a potential for clinical type 1 responses on reexposure to antigen(s). Mast cells, like basophils, express high affinity surface IgE receptors and despite a number of important differences between the two cell types they are often considered functionally analagous. ${ }^{22}$ If mast cells in the airways react like circulating basophils in response to viral antigen(s) the scene is then set for local release of histamine in the airways on repeated exposure to respiratory syncytial virus. Neither the time course of acquisition nor the duration of latent sensitivity to respiratory syncytial virus infection is known, and its association with respiratory outcome is speculative.

\section{LATENT SENSITIVITY AND SUBSEQUENT LUNG FUNCTION}

These data confirm reports of abnormalities in lung function during the months after recovery from acute bronchiolitis. ${ }^{23}$ Hyperinflation was much less common than at least one recent report suggests, ${ }^{24}$ the result perhaps of improvements in methods. ${ }^{25}$ The introduction of the technique for recording partial expiratory flow volume curves in infancy gives additional information. A decrease in VmaxFRC values immediately after an attack of bronchiolitis with a return to normal after six months has been reported in infants with mild bronchiolitis who were not admitted to hospital. ${ }^{26}$ Our results, in infants in hospital, show that severe limitation of airflow can persist for at least eight months after the acute illness, even in infants who are free of symptoms.

A technique for carrying out inhalational challenge studies in infants has recently been described. ${ }^{10}$ Normal data in infancy are scanty but Le Souef et al reported a range for $\mathrm{PD}_{30}$ to histamine of $0.3-5 \cdot 1 \mathrm{~g} / 1$ (geometric mean 1.4 $\mathrm{g} / \mathrm{l}$ ) in 12 apparently normal infants at a mean age of 7.8 months. ${ }^{27}$ The infants that we studied come at the lower end of this range. Tepper et al have recently reported that infants with a history of bronchiolitis have heightened airway reactivity to methacholine when compared with controls. ${ }^{28}$ One of the original aims in this study-paired histamine challenges for each infant during the nine months after an attack of acute bronchiolitis-proved impossible, as the unexpected severity of airways dysfunction limited the histamine challenge to only four infants at the first test, and to nine infants eight months after their original illness.

The interpretation of the results of lung function tests in the follow up of acute bronchiolitis may be confounded by the effects of other respiratory viruses that the infants encounter in the interim period. Two of our original cases acquired adenovirus infections that could have accounted for the severe clinical 
symptoms and abnormalities of lung function that we observed. Most other infants reported 'colds' during the nine month study period and some may have been reinfected with respiratory syncytial virus. Although we identified the infants who developed latent 'sensitivity' during attacks of acute bronchiolitis, we have no information on how long it lasts or how it is affected by subsequent respiratory syncytial virus infection.

Although allergic sensitisation of the airways may be a factor that contributes to morbidity after respiratory viral infection, there are other postulated mechanisms for airway injury or infection, or both, which could mask the effect of any single factor. The apparent similarity of respiratory outcome for 'sensitised' and 'nonsensitised' infants studied over a relatively short period of time does not necessarily preclude a 'sensitising' role for respiratory syncytial virus infection that contributes both to pulmonary dysfunction and hyper-responsiveness of airways after attacks of acute bronchiolitis. Systemic sensitisation has previously been connected with airways hyper-responsiveness of airways in adult asthmatic patients. ${ }^{30}$

\section{CONCLUSION}

The results of antigen challenge in infants with bronchiolitis and a group of control infants suggest that latent sensitivity to respiratory syncytial virus infection occurs during the course of attacks of bronchiolitis. Further studies are indicated to confirm this, including a controlled virus challenge and challenges with individual purified components of respiratory syncytial virus that may be of importance in the pathogenesis-for example, glycoproteins F and $G$, and measurements of antirespiratory syncytial virus IgE after infection. ${ }^{31}$ Further studies should also take account of the respiratory syncytial virus subtype. Ideally, future follow up assessments of lung function should include a measure of 'sensitivity' at the time of testing.

We thank Dr J Scott, Institute of Research on Animal Disease, Compton, Berkshire, for the preparation and supply of the respiratory syncytial virus and control tissue cultures; Professo RRA Coombs for his encouragement and helpful discussion and SJC gratefully acknowledges the financial support provided by a Medical Research Council intercalated award.

1 Clarke SKR, Gardner PD, Poole PM, Simpson H, O'H Tobin J. Respiratory syncytial virus infection: admissions to hospital in industrial, urban and rural areas. Report to the Medical Research Council subcommittee on respiratory syncytial virus vaccines. $\mathrm{Br}$ Med $\mathcal{f}$ 1978;ii:796-8.

2 Scott DG, Gardner PS, McQuillin J, Stanton AN, Downham MAPS. Respiratory viruses and cot death. Br Med $\mathcal{F}$ 1978;ii:12-3.

3 Pullan CR, Hey EN. Wheezing, asthma and pulmonary dysfunction ten years after infection with respiratory syncytial virus in infancy. $B r$ Med $\mathcal{J}$ 1982;284:1665-9.
4 Mok JYQ, Simpson H. Outcome of acute lower respiratory tract infection in infants: preliminary report of seven-year follow-up study. $\mathrm{Br} \mathrm{Med}$ J 1982;285:333-7.

5 Parish WE, Barrett AM, Coombs RRA, Gunter M, Camps FE. Hypersensitivity to milk and sudden death in infancy. Lancet 1960;ii:1106-10.

6 Parish WE, Barrett AM, Coombs RRA. Inhalation of cows' milk by sensitised guinea-pigs in the conscious and anaesthetised state. Immunology 1960;3:307-24.

7 McLaughlan P, Coombs RR. Latent anaphylactic sensitivity of infants to cows' milk proteins. Histamine release from blood basophils. Clin Allergy 1983;13:1-9.

8 Ashmore SP, Thomson AH, Simpson H. A high-performance liquid chromatographic technique for the rapid determination of histamine in both the plasma and cellular components of blood. $\mathcal{F}$ Chromatogr 1989;496:435-40.

9 Silverman M, Prendiville A, Green S. Partial expiratory flowvolume curves in infancy: technical aspects. Bull Eur volume curves in infancy: technical
Physiopathol Respir 1986;22:257-62.

10 Prendiville A, Green S, Silverman M. Bronchial responsiveness to histamine in wheezy infants. Thorax 1987;42:92-9.

11 Haydik IB, Ma W-S. Basophil histamine release: assays and interpretation. Clin Rev Allergy 1988;6:141-62.

12 Ahluwalia G, Embree J, McNicol P, Law B, Hammond G. Comparison of nasopharyngeal aspirate and nasopharyngeal swab specimens for respiratory syncytial virus diagnosis by cell culture, indirect immunofluorescence assay, and enzyme linked immunosorbent assay. $\mathcal{f}$ Clin Microbiol 1987;25:736-67.

13 Hall CB, Douglas RG, Geiman JM. Respiratory syncytial virus infections in infants: quantitation and duration of shedding. $\mathcal{F}$ Pediatr 1976;89:11-5.

14 Pruzansky JJ, Patterson R. Histamine release from leukocytes of hypersensitive individuals. 11. Reduced sensitivity of leukocytes after injected therapy. Foumal of Allergy 1967;39:44-50.

15 Norrby E, Mufson MA, Sheshbaraderan H. Structural differences between subtype A and B strains of respiratory differences between subtype A and B strains

16 Welliver RC, Kaul TN, Ogra PL. The appearance of cellbound IgE in respiratory-tract epithelium after respiratory syncytial virus infection. $N$ Engl $\mathcal{J}$ Med 1980;303: syncytial

17 Welliver RC, Wong DT, Sun M, Middleton EJ, Vaughan RS, Ogra PL. The development of respiratory syncytial virus-specific IgE and the release of histamine in nasopharyngeal secretions after infection. $N$ Engl $\mathcal{f}$ Med 1981;305:841-6.

18 Toms GL, Scott R. Respiratory syncytial virus and the infant immune response. Arch Dis Child 1987;62:544-6.

19 Scott R, Pullan CR, Scott M, McQuillin J. Cell-mediated immunity in respiratory syncytial virus disease. $7 \mathrm{Med}$ Virol 1984;3:105-14.

20 Isaacs D, Bangham CRM, McMichael AJ. Cell-mediated cytotoxic response to respiratory syncytial virus in infants with bronchiolitis. Lancet 1987;ii:769-71.

21 Welliver RC, Kaul TH, Sun M, Ogra PL. Defective regulation of immune responses in respiratory syncytial regulation of immune responses in respiratory

22 Schulman ES, MacGlashan DW, Schleimer RP, et al. Purified human basophils and mast cells: current concepts Purified human basophils and mast cells: current conc
of mediator release. Eur $\mathcal{I}$ Resp Dis 1983;64:53-61.

23 Seidenberg J, Masters IB, Hudson I, Olinsky A, Phelan PD. Disturbance in respiratory mechanics in infants with bronchiolitis. Thorax 1989;44:660-7.

24 Henry RL, Milner AD, Stokes GMM, Hodges IGC Groggins RC. Lung function after acute bronchiolitis. Arch Dis Child 1983;58:60-3.

25 Silverman M, Thomson A, Stock J, Elliott J. Lung function after acute bronchiolitis. Arch Dis Child 1983;58:65.

26 Rosenberg D, Tsangaris M, Eigen H, Tepper R. Outpatient bronchiolitis longitudinal evaluation. Am Rev Respir Dis 1989;139(suppl 2):A317.

27 Le Souef PN, Geelhoed GC, Turner DJ, Morgan SEG, Landau LI. Response of normal infants to inhaled histamine. Am Rev Respir Dis 1989;139:62-6.

28 Tepper R, Rosenberg D, Montgomery G, Tsangaris $M$ Heightened airway reactivity in infants following bronHeightened airway reactivity in infants following

29 Gaddy JN, Busse WW. Enhanced IgE-dependent basophil histamine release and airway reactivity in asthma. Am Rev histamine release and airway
Respir Dis 1986;134:969-74.

30 Simpson $\mathbf{H}$. Viral infection and asthma. In: Herzog $\mathbf{H}$, Perruchoud AP, eds. Progress in respiration research. Asthma and bronchial hyperreactivity. Vol 19. Basle: Karger, 1985: $181-8$.

31 Taylor G, Stott EJ, Bew M, et al. Monoclonal antibodies protect against respiratory syncytial virus infection in mice. Immunology 1984;52:137-42. 